\title{
Is Conversion Possible? A Review of a Swedish Study
}

\author{
Sue Willett
}

According to the Stockholm International Peace Research Institute (SIPRI), world military expenditures exceeded $\$ 800$ bn in 1984. Large amounts of scarce human and material resources are absorbed by the arms race, in a world beset by mass unemployment, poverty and deprivation. On the basis of the Study on the Relationship between Disarmament and Development [United Nations 1981] the UN General Assembly, in 1982 called on all member states to initiate studies which would explore the possibilities for disarmament and defence conversion and the subsequent transfer of resources to development assistance. To date the only country to have seriously addressed itself to these recommendations is Sweden. The detailed report prepared by a Swedish team of experts led by Inga Thorsson entitled In Pursuit of Disarmament [Government of Sweden 1984], is the first serious national programme for defence conversion to have been produced.

The main concern of the report is to provide the Swedish Government with policy guidelines for the planned transfer of resources from military to civilian use, Detailed calculations are made for a gradual reduction of military expenditures which would involve the closing of military bases, the relocation and retraining of military personnel, the provision of alternative occupations for communities dependent on military bases and the conversion of the domestic defence industry to more socially useful production. Finally, the report suggests various measures which the government could adopt to increase Sweden's development assistance to the Third World.

In Pursuit of Disarmament cannot necessarily be taken as a blueprint for conversion which can be replicated by other countries. But it does provide valuable insights into the complexities of developing a nationally coordinated programme, offering some useful guidelines for proponents of disarmament and conversion. Some of these are outlined below.

1 I am grateful to the ESRC for financial support.

TDS Butherin. 1985, vol it no 4. Institute of Development Srudies. Sussex
In order to anticipate the nature of the problems that a conversion process has to address it is essential to look, in as much detail as possible, at the characteristics of the defence industry. The Swedish defence-industrial base shares common characteristics with other European defence sectors. These include the concentration of defence production in advanced technology, high value added sectors such as aerospace and electronics, high $\mathbf{R} \& \mathrm{D}$ intensity, the specialisation of production resources, a degree of excess capacity, marked differences between military and civil technologies within the same sectors, heavy state financing of development costs, and the high and, to a considerable extent, politically determined profitability of defence manufacturing.

The emphasis on quality and performance in specialised branches of the military sector has led to the acquisition of skills and, more particularly, to the adoption of attitudes towards design and production that would be out of place in most commercial fields, where high volume production and increased efficiency compete with quality as goals. This applies especially to the scientific and engineering labour that constitutes a large percentage of the militaryindustrial workforce. Thus the skills required of management in military-industrial enterprises are quite unique to this field. Likewise the techniques of lobbying the defence ministry and service personnel to secure defence orders differ fundamentally from commercial marketing practices.

Another characteristic of the defence industry which poses a problem to conversion, is that some of the capital equipment used in branches of defence production is highly specialised and lacks the flexibility required for civilian output. The extremely demanding military standards and specifications and the desire to have capacity available for mobilisation, contributes to the separation of the military from civilian industry. One of the more conspicuous results of this is that the defence industry tends to acquire a lot of excess capacity. 
There are many other features of the defence industry that tend to make the companies or enterprises involved reluctant to convert to civilian production. For example, defence work is paid for on a continuous basis, providing a very favourable cash flow situation, particularly for financially weak companies. Similarly, companies accustomed to performing low risk military R \& D tend to be understandably nervous at the prospect of committing their own resources to the development and production of commodities for the uncertain and competitive civilian market.

In view of these problems Thorsson outlines some of the essential conditions which must be guaranteed if the objectives of disarmament and conversion are to be met. Conversion is not simply a technical process. In fact, Thorsson believes that all the technical and social problems are soluble if the political environment is conducive to a solution. The support of both the government and of the defence workforce is essential. The political viability of conversion is dependent on the protection of jobs. Continued employment in the context of the restructuring of an industry can only be guaranteed if the government's industrial and economic policies are committed to maintaining the level of aggregate demand and employment in the economy as a whole and also in companies formerly dependent on defence orders.

In view of the dependence of the defence industrial sector on government, it is important that the conversion process be properly planned. Large-scale conversion to civil production has occurred in only a few instances in recent years and in all these cases government assistance was crucial. Government orchestration of conversion would include subsidies for investment, the guarantee of markets for alternative products, and a retraining programme for workers and management alike.

One factor which seriously complicates the conversion process is the lack of risk-capital. Companies dependent on the production of defence equipment, who lack a large expansive civil sector which could provide the resources for new projects, are faced with considerable difficulties in developing products for civilian markets. The provision of state financing for civil sector innovation is essential if conversion is to be successful.

A more contentious point argued by Thorsson is the importance of involving the interests and capabilities of management in the conversion process. Management embodies the structures which maintain current attitudes in the defence industry. Moreover, conversion often challenges management's prerogatives, particularly where workers are engaged in alternative product planning. Ideally management structures need to be dismantled and retrained. The same also applies to design teams whose attitudes about what constitutes technological advance have been structured around complex and sophisticated military technologies. A government committed to conversion has to confront the management and design structure of the major arms enterprises while gaining the support of the workers in the process.

There are a wide range of products which could be produced by a converted military industry, a combination of capital goods for industry and government, and of consumer goods. These might include such items as machine tools, health equipment, educational aids, transport and energy technologies and construction. There is the possibility of developing more socially and ecologically responsive technologies, but these require an adequate demand and proper market research. Market penetration is a difficult and costly process and generally new markets require considerable expertise to develop. The problem of ensuring adequate demand could, however, be alleviated if central and local government demand formed most of the market. Moreover, if trade was planned and import controls were imposed for a certain period of time, a breathing space could be provided for converted industries to establish new products and markets.

It is a commonly held assumption that one category of socially useful production that defence firms could convert to is the production of alternative technology for the Third World. Indeed, Thorsson lists a number of potential technologies including mining equipment, water power machinery, agricultural equipment and medical apparat us. However, as she points out, there are several implicit problems with these assumptions. Firstly, although there may be a demand for these technologies, the funds to purchase them are often lacking. Even if they are provided as gifts, there may not be the available skills or space parts to maintain the equipment in working order. Secondly, and more importantly, the transfer of such products from industrialised to less industrialised countries perpetuates a situation of technological dependence, which may retard the internal development process within Third World countries. A more appropriate development approach would be to assist in the development of local based industries and the training of local labour to enable Third World countries to break the chains of dependence. What needs to be challenged is the assumption that industrialised countries have the right to define what is appropriate for the Third World. A more genuine link between disarmament and development would be created if representatives from Third World countries could be engaged in the definition of their technology needs and the conditions under which the transfer of such 
technologies took place. This would create the basis for a more equal and constructive North-South dialogue.

Thorssen's major recommendation for linking Sweden's disarmament to development is through the transfer of resources from the military sector to an international disarmament fund for development. The idea of establishing such a fund was first mooted within the UN in the 1950s and has subsequently been resurrected by the United Nations Institute for Disarmament Research (UNIDIR) as the political expression of the relationship between disarmament and development. The impact of such a fund would be considerable if all the major industrialised countries reduced their military expenditure and transferred a percentage of the released resources to the fund. If present world military expenditure was to be reduced by a mere four or five per cent and the subsequent resources transferred to development aid, this would represent a doubling of present development assistance. Such a transfer would have a substantial effect on the development of Third World countries.

What can we learn from Thorssen's report about the possibility for conversion in other European countries? The characteristics that differentiate Sweden from other European countries with substantial arms industries may help to highlight the obstacles to disarmament and conversion. Over the last ten years Sweden has maintained an average military expenditure of 3.3 per cent of GDP out of which 30 per cent goes on equipment procured largely from the domestic defence industry. Under Swedish law the export of armaments is illegal. Moreover, the initiation of a conversion plan is itself an expression of Sweden's strong national commitment to détente and disarmament and the conviction that it is both politically important and economically advantageous to reduce industry's dependence on military orders.

In many other European countries however, the major obstacle to disarmament and conversion is the integration of national defence policies into the aims and objectives of the NATO alliance. NA TO's defence policy is based on a massive deployment of nuclear missiles. As (in effect) offensive first-strike weapons, they act to destabilise the world balance of power, while absorbing huge amounts of scarce resources.
Britain, which has the highest rate of defence spending in Europe, at 5.4 per cent of GDP in 1984 [SIPRI 1985], has more cause for concern over the economic effects of high military expenditure than most other countries. However, a precondition for disarmament and conversion would be some form of disengagement from NATO and the denuclearisation of its defence policy. Such a move would most probably require the conscious adoption of an alternative defence policy. However, denuclearisation and withdrawal from NATO would not in itself guarantee a process of disarmament. That would depend on what type of alternative defence policy was adopted and whether the political will for disarmament and conversion existed. To its advantage, Britain has a strong peace movement which has placed the issue of disarmament and conversion firmly on the political agenda.

In France, the picture is very different. France does not, though belonging to the NATO alliance, participate in its command structure. However, there is a strong political consensus in support of high military expenditure, which represented 4 . I per cent of GDP in 1984. National pride in France's independent nuclear deterrent and military technological achievements ensure the continuing existence of a large defence industry. France is now the third largest exporter of arms in the world, a situation actively supported by the government, which views the export of weapons as a major contributor to the country's balance of payments and an integral part of its trade and foreign policies.

Thus, in sum, the preconditions for disarmament and conversion in both France and Britain diverge widely from those established within Sweden. Both countries would first have to arrive at a political situation and defence policies similar to Sweden's before they could adopt a programme which linked disarmament and defence conversion to development.

\section{References}

Government of Sweden, 1984, In Pursuit of Disarmament Conversion from military to civil production in Siveden: vols $I A$ and IB. Report by the Special Expert: Inga Thorsson. Stockholm 